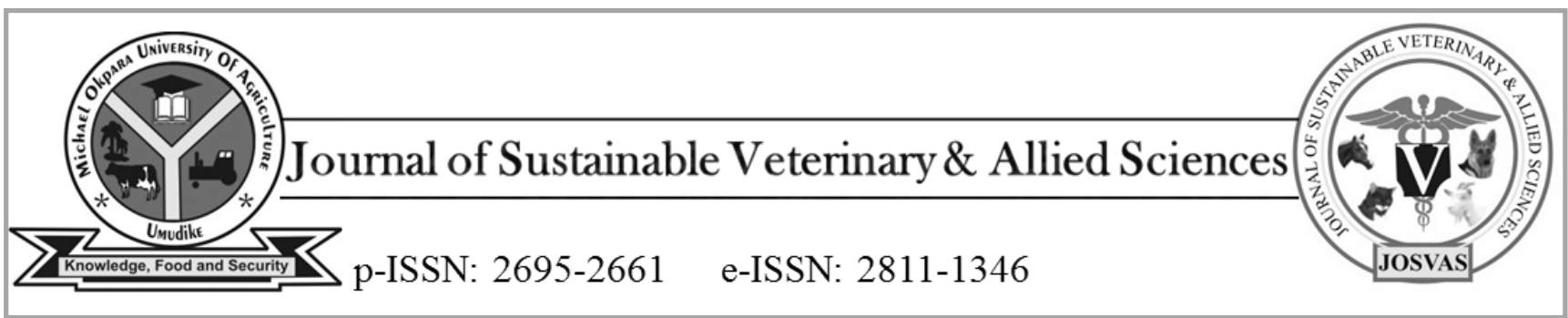

JoSVAS 2021, Vol 1, Issue 1: 20-24

C2021 College of Veterinary Medicine,

Michael Okpara University of Agriculture, Umudike, Nigeria

Original Research Article

\title{
Immune stimulation and antibody response of chicks to different doses/units of the Nigerian live infectious bursa disease vaccine

\author{
${ }^{1 *}$ Ezeibe, M. C. O., ${ }^{2}$ Adiele, I. A., ${ }^{1}$ Onyeachonam, F., ${ }^{1}$ Ogbonna, I. J., ${ }^{1}$ Akpan, C. A. \& \\ ${ }^{2}$ Okoroafor, $\mathbf{O}$. N.
}

${ }^{1}$ College of Veterinary Medicine, Michael Okpara University of Agriculture, Umudike, ${ }^{2}$ Department of Veterinary Medicine, University of Nigeria, Nsukka,, Nigeria

*Corresponding author: ezeibe.maduike@mouau.edu.ng, +2348138765566

\begin{abstract}
Vaccination failure is one of the major constraints to disease control in poultry. To investigate Infectious bursa disease (IBD)vaccination failures (frequently/globally reported), batches of the Nigerian live-vaccine were tested for viral units before vaccinating following chick-groups: 16 doses (65,536 units), 8 doses (32,768 units), 4 doses (6,384 units), 2 doses (8,192 units), 1 dose (4,096 units), 1:2 dose (2,048 units), 1:4 dose (1,024 units), 1:8 dose (512 units), 1:16 dose (256 units) and control. Each batch gave 4,096 viral units. Mean bursa weight/body weight ratios (immune stimulation) and mean antibody titres of the chick-groups were $47.40 \pm 5.45$ and $51.20 \pm 7.83 ; 44.25 \pm 7.28 \& 48.00 \pm 9.24 ; 45.25 \pm 4.28$ and $64.00 \pm 0.00$; $43.00 \pm 7.58$ and $101.60 \pm 35.05 ; 44.60 \pm 5.51$ and $128.00 \pm 0.00 ; 42.60 \pm 6.23$ and $268.80 \pm 16.00 ; 40.50 \pm 1.76$ and 80.00 $\pm 16.00 ; 31.40 \pm 3.80$ and $80.00 \pm 27.71 ; 37.18 \pm 4.07$ and $89.60 \pm 15.68$ and $26.20 \pm 3.31$ and $19.20 \pm 5.99$, respectively. Half (2,048 units) of the recommended 1-dose gave optimal antibody-titre. The higher doses gave lower antibody-titres like the lower doses but immune stimulation continued to increase as doses/units increased. Both over-stimulating the immune system (too high vaccine-doses/viral-units/viral-virulence) and under-stimulation cause vaccination failure.
\end{abstract}

Keywords: Infectious bursa disease, immunodeficiency, vaccine-overdose/underdose.

\section{INTRODUCTION}

Infectious bursal disease (IBD), an immune-deficiency disease, is a major challenge to the poultry industry in many countries (Awan et al., 1994). IBD (Gumboro disease) is one of the most important avian diseases, due to its economic impact on the poultry industry (Alexander et al., 1996). IBD causes high morbidity, high mortality and immunosuppression (Abdu et al., 1992). The disease is caused by a virus of the genus Avibirnavirus, of the family Birnaviridae.

Economic importance of Gumboro disease comes in two ways. Some strains of the virus cause mortalities ( $\geq 30 \%$ ) in chicks aged three to six weeks (Hussain et al., 2004) while others cause prolonged immune-suppression in chicks infected earlier than 3 weeks and in those that recover after clinical manifestations of the infection (Vanden-Berg, 2000). Immune-suppression increases risk of secondary infections and reduces antibody responses to vaccinations (Muller et al., 2003).

Vaccination and bio-security are major control measures for IBD in many countries (De Wit, 2001). Age of chicks at the time when IBD vaccination is administered, type of the vaccine, level of maternal antibody in the chicks at the time they are vaccinated and virulence of IBDV strains in the locality have been reported to affect response of chicks to IBDV vaccination (Hair-Bejo et al., 2004). Phatak (2000) also suggested quality of IBD vaccines, conditions of vaccine transportation, vaccine-storage, method of vaccinedistribution, time interval between vaccine-reconstitution and administration, presence of maternal antibodies in chicks, level of stress caused by the vaccination process, immune-suppression factors and routes of vaccination as causes of IBDV-vaccination failures.

Both live and killed vaccines are used in efforts to control IBD. Reports have shown that with IBD (unlike other 
diseases) live vaccines induce less antibody responses than killed vaccines and that immunity from the live vaccines lasts for shorter periods (Phatak, 2000). A comparative seroevaluation of live and killed Gumboro vaccines by RajKumar, et al. (2003) showed that antibody titers of chicks vaccinated with killed vaccines was 3,282.10 while that of the group vaccinated with live vaccine was only 1,513 .

In spite of many vaccination efforts made to control IBD, outbreaks keep occurring, even among vaccinated flocks (Zeleke et al., 2005). Butcher \& Miles (1994) suggested causes of IBD-vaccination failures to be high level of maternal antibodies in chicks vaccinated with live vaccines, inactivation of live vaccines due to improper handling or improper administration, vaccines not containing proper strains or serotypes of IBDV and chicks being vaccinated when they are already incubating the infection. Others include immune-suppression in chicks due to earlier infection with immune-suppressive pathogens, ingestion of mycotoxins and low virus titres in the vaccines.

This work was therefore designed to study how IBD virus doses/units of the Nigerian IBD vaccine (live vaccine) affect bursa-stimulation of vaccinated chicks and titters of IBDantibody in the chicks.

\section{MATERIALS AND METHODS}

One hundred and twenty (120) day-old chicks, in 10 groups, were kept on deep litter system and given feed and water, $a d$ libitum. They were allowed to acclimatize for 21 days and were vaccinated against Newcastle disease. To determine units of IBD virus in the Nigerian brand of the IBD vaccine (National Veterinary Research Institute, Vom, Nigeria), each 200 dose vial (of 5 different batches of the vaccine) was reconstituted with $10 \mathrm{ml}$ of $\mathrm{PBS}$ and was tested for viral titers by the modified passive haemagglutination test (Ezeibe et al, 2012).

To sensitize Red blood cells (RBC) for the test, serial double dilutions of the reconstituted vaccine were made in phosphate buffered saline (PBS), in wells of a "V"-bottomed microtitre plate. Then, $0.03 \mathrm{ml}$ of $0.4 \%$ Human group $\mathrm{O}$ RBC, prepared as described by Wosu, (1984), was added to each vaccine-dilution. The vaccine-RBC mixtures were tapped to mix well and incubated at $37^{\circ} \mathrm{C}$ for 15 minutes. In a second microtitre plate, $0.03 \mathrm{ml}$ of IBD-positive serum was deposited in each well in a row. Equal volumes $(0.03 \mathrm{ml})$ of the sensitized RBCs (from the first microtitre plate), were transferred to wells of the second microtitre plate, corresponding to dilutions of the IBD vaccine used to sensitize them. RBC control wells, containing only PBS and RBCs were included in the protocol. The setup was incubated at $37^{\circ} \mathrm{C}$ till RBCs in the control wells settled to discrete buttons. Reciprocal of highest dilution of the IBD vaccine used to sensitize RBCs that gave complete passive agglutination was read as IBD viral unit of the vaccine.
To make one drop $(0.05 \mathrm{ml})$ of the reconstituted IBD vaccine 16 doses instead of one dose, a 200 dose vial was reconstituted with $0.625 \mathrm{ml}$ ( $10 \mathrm{ml}$ divided by 16) of distilled water. Then $0.3 \mathrm{ml}$ of the reconstituted vaccine was serially double diluted, to get 8 doses, 4 doses, 2 doses, 1 dose, 1:2 dose, 1:4 dose, 1: 8 dose and 1:16 dose. Viral units in each of the doses were calculated from viral units of the reconstituted vaccine before they were used to vaccinate 10 groups of three weeks-old chicks as follows: 16 doses (65,536 units), 8 doses (32,768 units), 4 doses (6,384 units), 2 doses (8,192 units), 1 dose (4,096 units), 1:2 dose (2,048 units), 1:4 dose (1,024 units), 1:8 dose (512 units), 1:16 dose (256 units) and control

Three weeks post vaccination, each chick in each of the ten groups was bled through the wing vien and the serum used for PHA test, to determine its IBD antibody titer, as described by Aliev et al. (1990) and Rahman et al,. (1994).

To determine rates of immune stimulation in the chicks, they were weighed and then sacrificed. Their bursae were weighed and their bursa-weight/body-weight ratios (BBR) calculated by the formula described by Closser (1990). Means of bursa-weight/body-weight ratios and means of antibody titre of the ten groups were compared by one-way analysis of variance (ANOVA). Graphs of mean bursa weight/body weight ratio and means of antibody titres of the groups were plotted against, doses/viral-units used to vaccinate their groups.

\section{RESULTS}

Each of the five IBD vaccine-batches gave viral titre of 4,096. Mean antibody titre $(268.8 \pm 99.97)$ of the group vaccinated with 1:2-dose (2,048 units) was significantly higher $(\mathrm{P} \leq 0.05)$ than those of all other groups. All the doses lower than the recommended one dose per chick produced antibody titers $>64$ (PHA protective antibody titrefor IBD). Of the higher doses, only 2-doses gave titre $>64$. Doses 8 and 16 failed to produce titers $\geq 64$ (Table 1 ).

Each of the five IBD vaccine-batches gave viral titre of 4,096. Mean antibody titre $(268.8 \pm 99.97)$ of the group vaccinated with 1:2-dose (2,048 units) was significantly higher $(\mathrm{P} \leq 0.05)$ than those of all other groups (Figure I). All the doses lower than the recommended one dose per chick produced antibody titres $>64$ (PHA protective antibody titre for IBD). Of the higher doses, only 2-doses gave titre $>64$. Doses 8 and 16 failed to produce titres $\geq 64$ (Table 1).

Mean bursa-weight/body-weight ratio of the group of chicks vaccinated with 16 doses (65,536 MPHAUs) of the live IBDV vaccine was the only one significantly $(\mathrm{P} \leq 0.05)$ higher than mean bursa-weight/body-weight ratio of the control (Figure II). Means of the bursa-weight/body-weight ratios of the other vaccinated groups did not vary from mean of the control group, nor, from that of the group vaccinated with 16 doses (65,536 MPHAUs) (Table II). 
TABLE 1: Passive haemagglutination antibody titres of chicks vaccinated with different doses (units) of the Nigerian Infectious bursa disease (live) vaccine.

\begin{tabular}{ccl}
\hline Vaccine-Doses & $\begin{array}{c}\text { Vaccine- } \\
\text { MPHAUs }\end{array}$ & $\begin{array}{l}\text { Mean antibody } \\
\text { titres } \pm \text { SEM }\end{array}$ \\
\hline 16 doses & 65720 & $51.20 \pm 7.83^{\mathrm{a}}$ \\
8 doses & 32688 & $48.00 \pm 9.24^{\mathrm{a}}$ \\
4 doses & 16383 & $64.00 \pm 00.00^{\mathrm{a}}$ \\
2 doses & 8192 & $101.60 \pm 35.05^{\mathrm{a}}$ \\
1 dose & 4096 & $128.00 \pm 00.00^{\mathrm{a}}$ \\
$1: 2$ dose & 2048 & $268.80 \pm 99.97^{\mathrm{b}}$ \\
$1: 4$ dose & 1024 & $80.00 \pm 16.00^{\mathrm{a}}$ \\
$1: 8$ dose & 512 & $80.00 \pm 27.71^{\mathrm{a}}$ \\
$1: 16$ dose & 256 & $89.60 \pm 15.68^{\mathrm{a}}$ \\
Control & 0 & $19.20 \pm 5.99^{\mathrm{a}}$ \\
\hline
\end{tabular}

TABLE II: Bursa weight/body weight ratios $(x$ $10^{-4}$ ) of chicks vaccinated with different doses (units) of the Nigerian Infectious bursa disease (live) vaccine.

\begin{tabular}{rcl}
$\begin{array}{r}\text { Vaccine- } \\
\text { Doses }\end{array}$ & $\begin{array}{r}\text { Vaccine- } \\
\text { MPHAUs }\end{array}$ & $\begin{array}{l}\text { B/BR } \\
\text { (stimulation) } \\
\text { (Mean- } \pm \text { SEM) }\end{array}$ \\
\hline 16 & 65720 & $47.40 \pm 5.45^{\mathrm{b}}$ \\
8 & 32688 & $44.25 \pm 7.28^{\mathrm{ab}}$ \\
4 & 16383 & $45.25 \pm 4.28^{\mathrm{ab}}$ \\
2 & 8192 & $43.00 \pm 7.58^{\mathrm{ab}}$ \\
1 & 4096 & $44.60 \pm 5.51^{\mathrm{ab}}$ \\
$1: 2$ & 2048 & $42.60 \pm 6.23^{\mathrm{ab}}$ \\
$1: 4$ & 1024 & $40.50 \pm 1.76^{\mathrm{ab}}$ \\
$1: 8$ & 512 & $31.40 \pm 3.80^{\mathrm{ab}}$ \\
$1: 16$ & 256 & $37.18 \pm 4.07^{\mathrm{ab}}$ \\
Control & 0 & $26.20 \pm 3.31^{\mathrm{a}}$ \\
\hline
\end{tabular}

\section{DISCUSSION}

All 5 batches of the Nigerian live IBDV vaccine had the same viral units. This may be as a result of good quality control measures by the laboratory that produces it. From 1: 16 dose to 1: 2 dose (256 - 2048 MPHAUs), both mean bursa-weight/body-weight ratios and mean antibody titres increased. This suggests that increasing IBDV units of the vaccine increases immune-stimulation and antibody responses in chicks. From 1-dose of the vaccine to 16-doses (4,096 - 65,536 MPHAUs), while bursa weight-body weight ratios continued to increase, mean antibody titres decreased. This suggests that over stimulation leads to reduction in antibody response of vaccinated chicks. The reduction in antibody responses may be due to depletion of lymphocytes by the live IBD viruses used as vaccine. Kulikova et al. (2004) had already reported that chicks vaccinated with milder vaccines (milder stimulation) had higher antibody titres than those vaccinated with vaccines of more pathogenic strains. That report shows that, the more pathogenic ("hot") IBD vaccines deplete more lymphocytes (the immune cells) than the milder vaccines while present finding suggests that higher units of IBD virus in the vaccine also lead to depletion of more lymphocytes.

Hair-Bejo et al. (2004) suggested that low IBD antibody titre in vaccinated chicks may be due to failure of viruses in vaccines to achieve enough stimulation of the bursa of Fabricius but results of this study suggest that both under stimulation and over stimulation lead to same low antibody titres. Amount of live viruses in vaccines and their virulence affect amount of antibodies produced.

Depletion of lymphocytes by infections that cause immunedeficiency such as IBDV would reduce titres of antibody produced because lymphocytes (immune-cells) produce the antibodies. Luengo et al. (2001) reported that reduction in bursa-weight/body-weight ratios was associated with low antibody titres. Also, Abu \& Al-Mayah (2009) reported that a highly attenuated intermediate vaccine could not destroy B-lymphocytes in the bursa of Fabricius while a vaccine with a more pathogenic virus did. So, the practice of giving more than one dose of IBD vaccine to a chick or use of vaccines that are too high in virulence ("hot vaccines") could lead to depletion of lymphocytes and cause immune deficiency as observed in the groups vaccinated with doses ranging from 1 to 16 in this study.

Hair-Bejo et al. (2000) reported that the "hot" IBD vaccines caused immune-suppression due to severe damage they caused in the bursa of Fabricius. Also, vaccines too low in titre or too low in virulence may not stimulate the bursa enough and so would lead to low antibody titres (groups vaccinated with doses ranging from 1: 4 to $1: 16$ ).

Field outbreaks of infectious bursa disease are characterized by immune deficiency. So, when there is poor stimulation of the bursa and field infections occur, the results are low lymphocytes counts, low level of antibodies and clinical signs (Alloui et al., 2005). As a result of these similarities in haematology, serology and clinical manifestations of IBD and manifestations of IBD-vaccine-overdose, researchers and clinicians all over the world, keep thinking that the problem is only vaccination failure. Therefore, efforts so far have been to enhance bursa stimulation by increasing either units of the virus used as vaccines (using more than one dose per chick) or virulence of virus strains used as vaccines or both the viral-units and the virulence. The fact that these viral-units could lead to depletion of the lymphocytes is often not considered Passive haemagglutination antibody titre that protects chicks against IBDV challenge is 64 (Lukert \& Saif, 2003). That means that in this study, only 


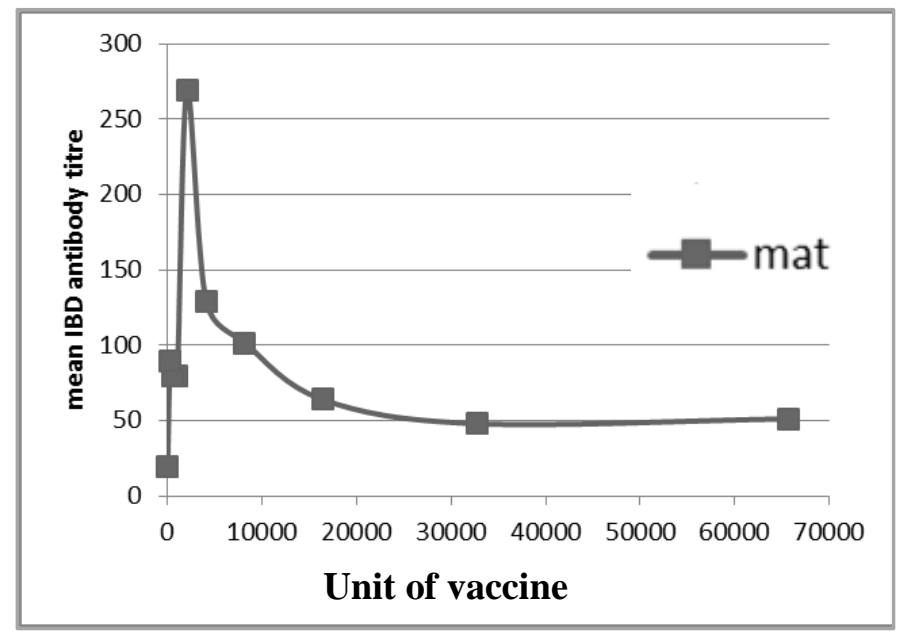

FIGURE I: Humoral immune responses (Mean antibody titres) of groups of chicks vaccinated with the Nigerian live Infectious bursal disease vaccine.

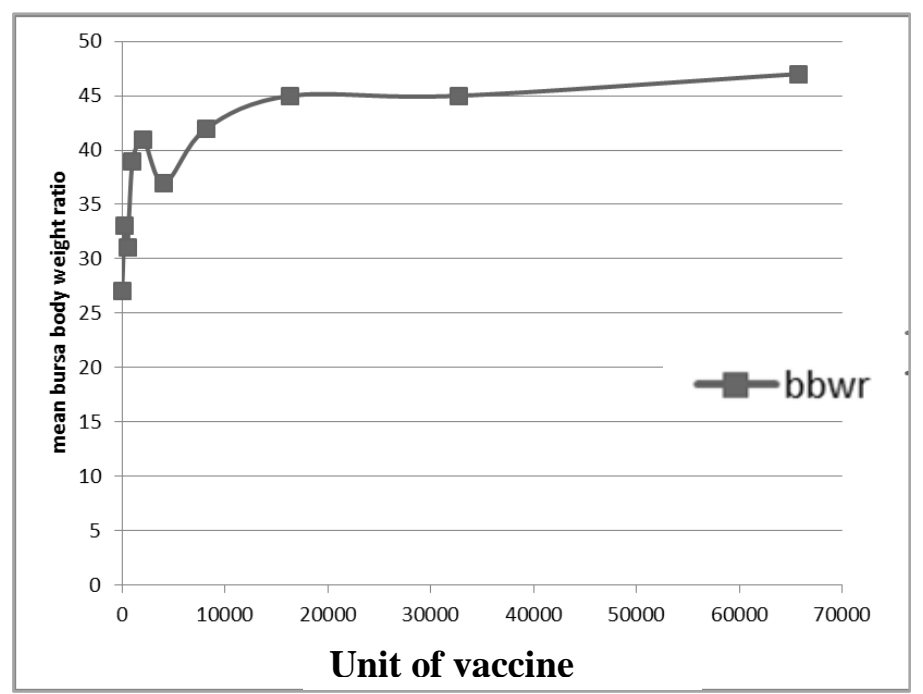

FIGURE II: Bursa-body weight ratios (immune stimulationrates) of chicks vaccinated with the Nigerian live Infectious bursa disease vaccines

16-doses (65,536 MPHAUs) and 8-doses (32,768 MPHAUs) failed to produce protective antibodies levels.

That doses lower than the recommended 1-dose $(2,048$ MPHAUs - 256 MPHAUs) and doses higher than $1(8,192$ MPHAUs -16,536 MPHAUs), produced protective titres ( $\geq$ 64) may be contributing to the confussion. That may be reason scientists and clinicians keep claiming successes with different doses and with different units and virulence of IBD vaccines while the problem persists. There is need to determine correct units and correct virulence of IBDVvaccines for optimal immune response.

Animoke (2011) has reported that IBD antibodies wane very fast under tropical conditions. So, titres just above 64 may drop to below the protective antibody level before vaccinated chicks pass age of the disease. IBD-vaccination should produce titre reasonably higher than 64 so that even with the rapid decay, antibodies in chicks can remain above the protective titre long enough to allow chicks pass the critical age of IBD. From results of this study, 1: 2 dose (2,048 MPHAUs) of the Nigerian live IBD vaccine gives that required high immune response $(268.8 \pm 99.9)$.

That mean weight of bursae of chicks became significantly higher following vaccination with 16 doses of the live vaccine in this study is evidence that the vaccine adequately stimulates the bursa. Apart from stimulating production of antibodies, IBD virus causes destruction of the bursa of Fabricius (Muller et al., 1979). So, overstimulation of the bursa by live IBD vaccines can lead to depletion of the Blymphocytes and destruction of bursa of Fabricius which will then cause reduction in level of immune responses of chicks to IBD vaccination and to vaccinations against other diseases (Kulikova et al., 2004).

The fact that the control group had the least bursa-weight/body-weight ratio and negligible antibody titre supports the observation by Kulikova et al. (2004) that IBD-vaccinated chicks which had statistically insignificant BF index produced the lowest average post vaccination antibody titres. So, both overvaccination and under-vaccination result to same low antibody titres.

Sero-conversion which occurred in the control group suggests that they may have been exposed to low dose of the live IBDV. That IBDV infection can occur through insects and formites have already been reported (Benton et al., 1967). However, the significantly low mean antibody titre of that group shows that dose of the vaccine that they were exposed to, was negligible.

To avoid the two problems (IBDV vaccination failure and IBDV vaccine-induced immune deficiency), it is better that viral units of each vaccine-brand be determined before deciding to increase or to reduce the dose to use in vaccinating chicks. With the Nigerian IBD vaccine-brand, when the vaccine is well preserved, its viral units would be 4,096. So, to maximize immune response in vaccinated chicks, dose of the vaccine should be reduced by half (not increased by two as is being suggested).

Batches of the Nigerian IBD vaccine sourced from outside the production-unit (NVRI), produced mean viral units of only 2,048 (Oguniran, 2014). It is therefore suggested that the vaccine be well preserved first. Then the dose to be used for maximal antibody response would be 1:2 of presently recommended dose. So, best reconstitution rate for the 
Nigerian brand should be 200 doses in $20 \mathrm{ml}$ of saline instead of 200 doses in $10 \mathrm{ml}$.

\section{CONCLUSSION}

As doses/units of the Nigerian IBDV vaccine (live) increase, rates of immune-stimulation and rates of antibody responses increase (1: 16 - 1:2 doses of the vaccine) but beyond the optimal dose/unit (1:2 dose/2048 units), while rate of immune-stimulation continues to increase, antibody produced, decreases. This means that some outbreaks of IBD reported as vaccination failures could be vaccineinduced immuno-deficiency. That vaccination strategy which achieved antibody titreof $268.8 \pm 99.97$ may be effective in controlling IBD because such high antibody titre, if got from booster-vaccination (at third week of life), may not reduce bellow 64 (protective level) before they pass the critical age for the disease.

\section{REFERENCES}

Abdu, P.A., Mera, U.M. \& Saidu, L. (1992). A study on chicken mortality in Zaria, Nigeria. In Proceedings. $19^{\text {th }}$ World Poultry Congress, Amsterdam, The Netherlands, 20 - 24 September. Vol. 2.

Abu- Tabeekh, M.A.S. \& Al-Mayah, A.A.S. (2009). Morphological investigation of bursa of Fabricius of imported broilers and local chicks vaccinated with two types of infectious bursal disease vaccines. Iraqi. Journal of Veterinary Sciences, 23, 201-206.

Alexander, D.J. \& Chettle, N.J. (1998). Heat inactivation of serotype 1 infectious bursal disease virus. Avian Pathology, 27 (1), 97 - 99.

Alloui, M.N, Sellaouil, S. \& Djaaba, S. (2005). Morphometrical and anatomo-pathological survey of bursa of fabricius in broiler chicken. Avian Disease, 35, 450-469.

Animoke, P.C (2011). Seroprevalence of antibodies of IBD virus in day old chicks hatched in Southern Nigeria and effects of vitamin B complex on immune response of chicks to IBD vaccination. Dissertation. University of Nigeria, Nsukka.

Benton, W.J., Cover, M.S. \& Rosenberg, J.K. (1967a). Studies on the transmission of the infectious bursal agent (IBA) of chickens. Avian Dis. 11:430-438.

Butcher, G. D. \& Miles, R.D. (1995). Infectious bursal disease (Gumboro) in commercial broilers. http://edis.ifas.ufl.edu.

De Wit, J.J. (2001). Gumboro Disease: estimation of optimum time of vaccination by the Deventer formular. Annual report and Proceedings of COST Action 839: Imunosuppressive viral diseases in poultry Luxembeourg pp.170-178.

Ezeibe, M. C. O., Okoye, J.O.A., Ogunniran, T.M., Okoroafor, O.N, Ezeala, I.E. \& Ngene,A.A. (2012). Modification of the Passive Heamagglutination Test for Detection of Infectious Bursal Disease Virus. Health, 4, $653-655$

Ezeibe, M.C.O., Okoye, J.O.A., Ogunnira, T. M., Animoke, P.C., Mbuko, I.J., Nwankwo, I.A. \& Ngene A .A (2014). Effect of live infectious bursal disease vaccines, on immune response of vaccinated chicks. British Journal of Medicine and Medical Research, 4(7), 1806.

Giron, P.C. (1969). Algunos aspectos de la por el agents infeccioso de la bolsa de Fabricio en Mexico. Tec. Pecu., suppl. No 1, pp 98-104

Hair-Bejo, M. (2004). Day old vaccination against infectious bursal disease in broiler chickens. Asian Network for Scientific Information, International Journal of Poultry Science, 3, $124-128$.

Hussani, I., Atif, N.A., Ahmad, M., Ashfaque, M., Shahid, M. \& Masood, A. (2004). Pathogenic properties of infectious bursal disease vaccines. Pakistan Veterinary Journal, 21(4), 184-188.

Ide, P.R. \& Stevenson, R. G. (1973). Infectious bursal disease in New Brunswick. Canadian. Journal of Comparative Medicine, 37, 347-355.

Jackwood, D.J. \& Saif, Y.M. (1987). Antigenic diversity of infectious bursal disease viruses. Avian Disease, 31, $766-770$.

Kulikova, L, Jurajda V. \& Juranova, R. (2004). Effect of IBD vaccination strains on the Immune System of Leghorn Chickens. Acta Veterinaria Brno. 73, 205 209.

Lam, K.M. (1998). Alteration of chicken heterophil and macrophage functions by the infectious bursal disease virus. Microbial Pathogenesis, 25, 147-155.

Luengo, A., Butcher, G., Kozuka, Y. \& Mile, R. (2001). Histopathology and transmission electron microscopy of the bursa of Fabricius following IBD vaccination and IBD virus challenge in chickens. Revista Cientifica, 11(6), 533-544.

Lukert, P.D. \& Saif, Y.M. (2003). Infectious bursal disease. In Y. M. Saif, J. R. Glisson, A.M. Fadly, L. R. McDougald \& D.E. Swayne (Eds), Diseases of Poultry, $11^{\text {th }}$ edn (pp. 161-180). Ames: Iowa State University Press.

Muller, R., Kauffer-Weiss, I., Reinacher, M. \& Weiss, E. (1979). Immunofluorescent studies of early virus propagation after oral infection with infectious bursal disease virus. Zentralbl. Veterinar. Medizin Reihe B, 26, 345 -352.

Muller, H., Islam, M.R., \& Raue, R. (2003). Reseach on Infectious Bursal Disease- the present and the future .Veterinary Microbiology, 97, 153-165.

Ogunniran, T. M. (2014). Assessment of immunogenicity of five infectious bursal disease vaccines used in Nigeria. M.Sc Dissertation. University of Nigeria, Nsukka.

Phatak, R.K. (2000).Vaccination failure and their solutions.N50029 in Proceeding. Poultry Seminar, Hyderabad, India.

Raj-Kumar, B., Khaondoker, M.H., Bijon, K.S. \& Mohammed, T. (2003). Comparative seroprevalence of live and killed Gumboro vaccine in broilers. Italian Journal of Animal Science, 2,157162.

Article history: Received: May 3, 2021, Revised: August 2, 2021, Accepted: August 5, 2021 